\title{
ANALYSIS OF INNOVATION ACTIVITY OF SLOVAK AND CZECH ENTERPRISES
}

\author{
EMÍLIA SPIŠÁKOVÁ
}

\section{INTRODUCTION}

The term "innovation" is Latin origin (innovatio, innovare) and means the introduction of new or significantly improved product or service on the market, respectively introduction of new or significantly improved process within the company (Štatistický úrad SR, 2006). Innovation is obtained as a new combination of existing business technologies, new technological developments or use of business skills. Innovation can be developed by the company or other companies, and it should present something new to the company.

The base of innovation is the ability to see the relations, observe and exploit the opportunities. This is relative, radical and revolutionary changes in thinking, products, processes or organizations. In the literature we can find several different approaches to the definition of innovation. For example, European Commission defines innovation as the renewal and extension of scale of products and services and related markets, creating new methods of production, supply and distribution, introduction of changes in management, work organization, working conditions and changes in workforce skills (Klas, 2005).

Luecke and Katz define innovation from the perspective of the organization: "Innovation ... is generally regarded as the successful introduction of new things or methods ... Innovation is the personification, combination or synthesis of knowledge in original, relevant and valuable new products or services." (Luecke, Katz, 2003, p.3)

Innovation generally involves also creation. However these two terms can not be considered as synonyms. According to Teresa Amabile the innovation begins with creative idea and a successful implementation of this idea in the organization. Then the creativity of individuals and teams is base of innovation. It is necessary but not sufficient (Amabile, 1996).

Innovation can also be characterized in terms of organizational and management processes. According to Davil, is the innovation, like other business functions, management process requiring specific tools, tasks and discipline (Davila, Epstein, Shelton, 2006).

The term of innovation is often confused with the term of invention. Invention is only the first step in a long process in which a good idea is converted into a 
widely usable and effective product or service. Innovation therefore requires more than only come with a new idea, but it is the process of application of the idea in practice.

Current knowledge in the innovation that are reported in literature distinguish four basic types of innovation: product, process, organizational and marketing innovation. Product innovation is the introduction of new or significantly improved product. Process innovation is a new or significantly improved production method or the supply and distribution channel. These two types of innovation are associated with improving of existing or application of new technologies in the production, therefore they are often called "technological innovation".

Organizational innovation are the implementation of new or significant changes in corporate structure and marketing innovation are associated with the introduction of new or significantly improved product design and sales methods in order to increase the attractiveness of products and services or to enter in the new markets. These two types of innovation are also called "non-technological innovation", because they do not require the changes or introduction of new technologies, but they are oriented on the adoption of new business and organizational methods.

\section{INNOVATION ACTIVITY OF ENTERPRISES IN SELECTED COUNTRIES}

Innovation in the period of economic crisis become an essential assumption for business survival in a strong competitive fight. Information about the creation and implementation of innovation in this period are not yet available, so this article will use the last available data from Eurostat, i.e. data for the year 2006. On the basis of them a comparative analysis of innovation activities of Czech and Slovak enterprises will be realized and the cooperation in the development and implementation of innovation will be described.

In 2006 occurred in European Union 691,735 enterprises, of which only $38.87 \%$ were innovation active, i.e. they introduced only product innovation, only process innovation or both product and process innovation. The largest share on the total number of enterprises during the year 2006 had small enterprises with staff from 10 to $49(544,723$ enterprises), from which were only $34.40 \%$ innovation active (Figure 1). Followed the medium-sized enterprises with the number of staff from 50 to 249 (120,765 medium-sized enterprises from the total number of enterprises in EU27) and innovation active were 52.27\% of mediumsized enterprises.

From the total of 26,237 large enterprises (large enterprises are employing 250 or more employees) introduced during the year 2006 product, process or both product and process innovation 18,385 enterprises, i.e. $70.07 \%$. This reflects: 
- higher amount of funds destined for innovation in these enterprises,

- better access to foreign resources that will support innovative activity of enterprises,

- advanced machinery, equipment and software used in the production,

- high intellectual potential and also

- ability to withstand significantly higher risks associated with the introduction of innovation in comparison with small respectively mediumsized enterprises.

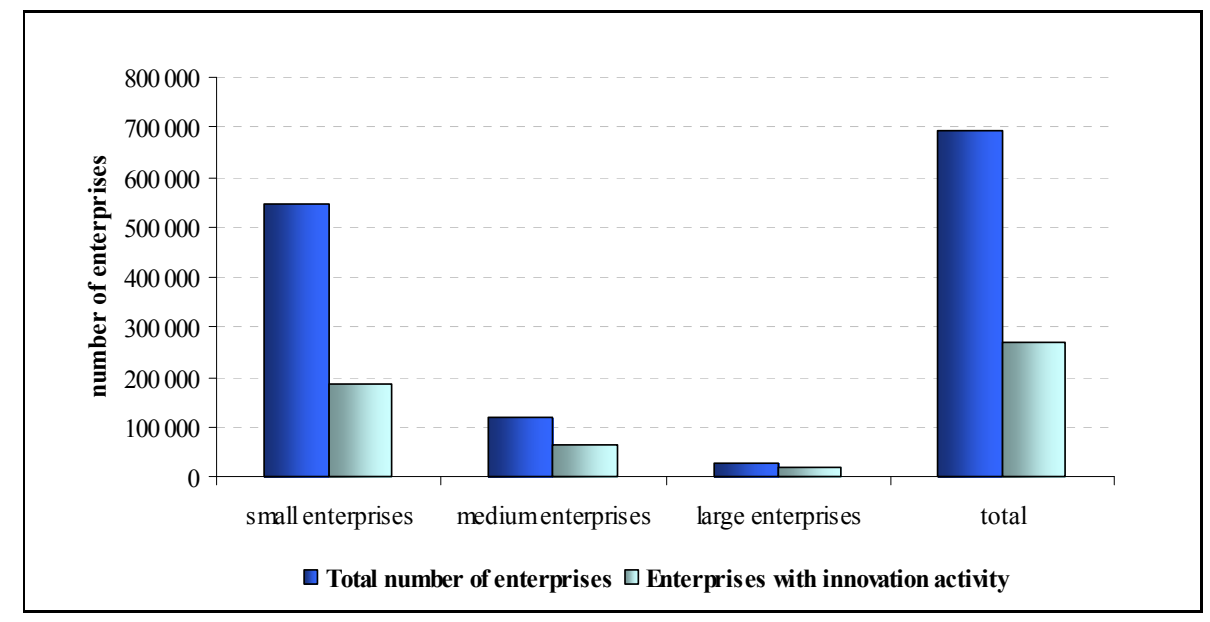

Figure 1 - The number of innovation active enterprises in EU 27 according to their size in 2006

The following parts of article deal with more detailed analysis of innovation activity of enterprises in two neighboring countries. Specifically, it is the analysis of innovation activity of enterprises according to their size, to the type of introduced innovation, according to the sector of their operation, organization which has developed a new product or process. There is also analyzed the cooperation in the development and implementation of innovation in enterprises with domestic institutions, but also with institutions outside the country, i.e. in the European Union, in other European countries or in the U.S., respectively other countries in the World.

We will use here standard methods, like a comparison, spatial and trend analysis, induction, deduction and synthesis.

\subsection{The innovation activity of Slovak enterprises}

Slovak Republic is the smallest country of V4 countries not only by its extent, but also by the number of the population. Together with the Poland and Hungary belongs country to the group of catching-up countries, whereby its innovation 
activity, which is evaluated by the Summary Innovation Index, is higher then the innovation activity of two mentioned countries from this group.

The size of country is also reflected in the number of enterprises in Slovak Republic (the lowest number of enterprises in comparison with the other V4 countries). From the number of 6,465 enterprises only $1 / 4$ of enterprises decided to create and implement some type of innovation (Table 1). The most of enterprises still regard this activity as expensive and very risky; therefore they prefer a simple way without the innovation. The most of product and process innovation were in the year 2006 implemented in the small enterprises, the least in large enterprises. Regardless of the size of enterprise, in the country predominated and still dominate the enterprises without the innovation activity.

Table 1 - Enterprises with innovation activity according to their size and the type of implemented innovation in Slovak Republic

\begin{tabular}{|l|c|c|c|c|c|c|c|}
\hline \multirow{2}{*}{$\begin{array}{l}\text { Size of } \\
\text { enterprise/type } \\
\text { of innovation }\end{array}$} & $\begin{array}{c}\text { Total } \\
\text { enterprises }\end{array}$ & Total & $\begin{array}{c}\text { Product } \\
\text { and } \\
\text { process } \\
\text { innovation }\end{array}$ & $\begin{array}{c}\text { Product } \\
\text { innovation }\end{array}$ & $\begin{array}{c}\text { Establish } \\
\text { Process } \\
\text { innovators, } \\
\text { ongoing and/or } \\
\text { abandoned } \\
\text { only }\end{array}$ & $\begin{array}{c}\text { Enterprises } \\
\text { without } \\
\text { innovation } \\
\text { activity }\end{array}$ \\
\hline $\begin{array}{l}\text { Small } \\
\text { enterprises }\end{array}$ & 4,575 & 874 & 257 & 218 & 342 & 57 & 3701 \\
\hline $\begin{array}{l}\text { Medium } \\
\text { enterprises }\end{array}$ & 1,459 & 492 & 217 & 113 & 147 & 16 & 967 \\
\hline $\begin{array}{l}\text { Large } \\
\text { enterprises }\end{array}$ & 431 & 242 & 148 & 29 & 57 & 7 & 189 \\
\hline
\end{tabular}

Source: self elaboration according to the data from Eurostat on 13.1.2010

According to the analyze of innovation activity of enterprises by the sector of their operation we can state, that in the year 2006 had the highest share the industrial enterprises, nearly $27 \%$ of enterprises innovated their production by the implementation of product, process or both product and process innovation (Figure 2). From the total number of enterprises, 2,828 enterprises didn't realized any innovation activity.

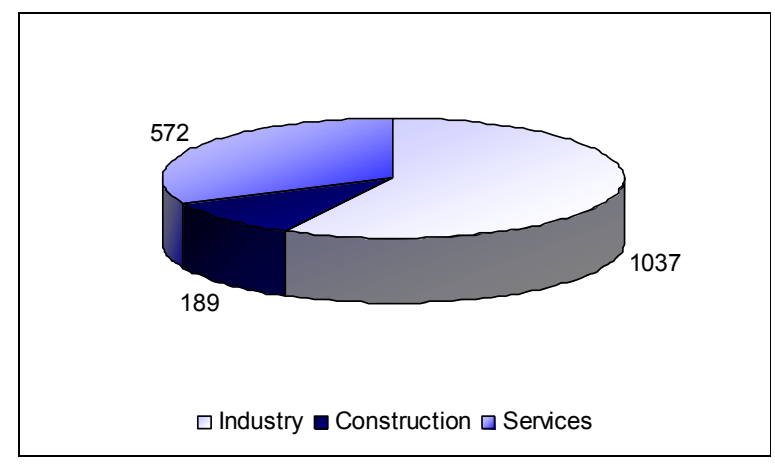

Figure 2 - The number of enterprises with innovation activity according to the sector of their operation in Slovak Republic 
The highest innovation activity was recorded in the industrial enterprises in the area of Manufacture of office machinery and computers, where exactly half of the enterprises in the year 2006 introduced some type of innovation. Less than half of innovative enterprises were from all other areas of industry, for example from the area of Manufacture of medical, precision and optical instruments, watches and clocks and Manufacture of electrical machinery and apparatus with the $43 \%$ share of enterprises with innovation activity on the total number of enterprises in this area.

On the other hand, the lowest innovation activity was observed in enterprises deals with the Collection, purification and distribution of water $(5.88 \%$ of enterprises), the Manufacture of wearing apparel, dressing, dyeing of fur clothing production, processing and dyeing of fur, the Manufacture of textiles and textile products, leather and leather products with around $10 \%$ share of innovative enterprises on the total number of enterprises in this area.

In the service sector has decided to improve their services or to improve the level of services supplying about half of the number of industrial enterprises (Figure 2 ), but their share on the total number of enterprises providing services was almost $22 \%$. These enterprises preferred process innovation, not product innovation.

The most of innovative services were provided by the enterprises in the area of Financial intermediation, except insurance and pension funding ( $62.22 \%$ of these enterprises provided new or improved service), also in the area of Research and development, with the $61.36 \%$ share of innovative enterprise on the total number of enterprises in this area, and in the area of Post and Telecommunications, where exactly $60 \%$ of enterprises decided to innovate providing services.

The lowest innovation activity, but not so much low than in the industrial sector, was in enterprises that realized Supporting and auxiliary transport activities, activities of travel agencies with the $13.48 \%$ share of innovative enterprises on the total number of enterprises in this area.

In the year 2006, enterprises in the construction sector were showed the lowest innovation activity. From the total of 1,526 construction enterprises, only $12.39 \%$ of enterprises innovated their production mainly by introducing new or significantly improved processes.

According to the analyze of innovation activity of enterprises operating in the different sectors according to their size we can state, that both in industrial and in service sector were the most numerous small enterprises, but the share of small innovative enterprises on the total number of small enterprises in industrial and service sector was the lowest (Figure 3). By contrast to this, the least numerous were large enterprises, of which over half enterprises decided to introduce the innovation in the year 2006. 

a) industry
b) services

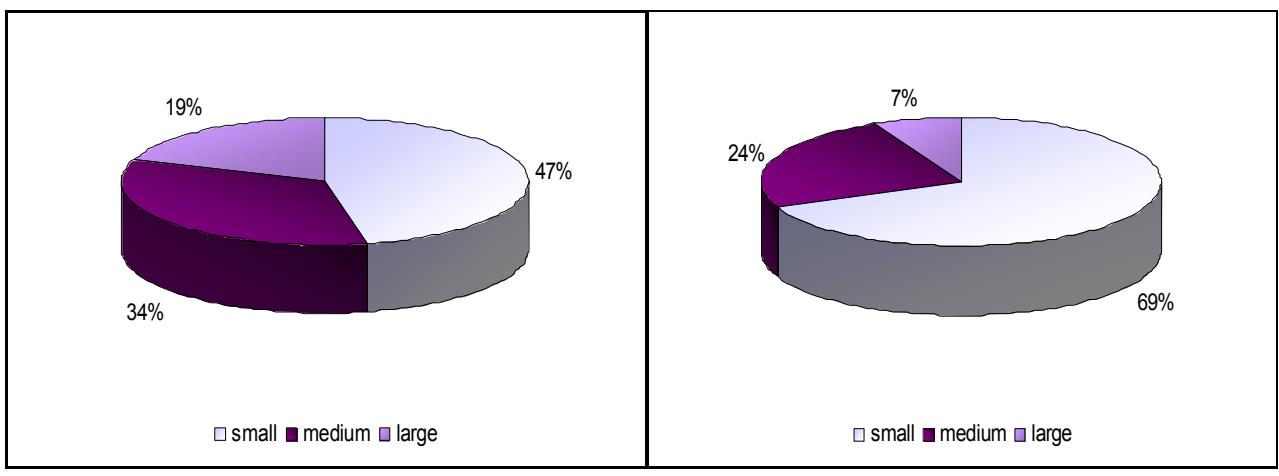

Figure 3 - Percentage share of small, medium and large innovation active enterprises in the total number of innovative enterprises in industry and services sectore in Slovak Republic

\subsection{The cooperation in creating and implementing innovation in Slovak Republic}

The development of new or significantly improved product and process may be involved in various enterprises, institutions. Innovation may be the result of the enterprise's activity or the activity of the group of enterprises that introduce it, the result of cooperation of particular enterprise with the other enterprises or may be fully developed by other companies, institutions.

According to data available from Eurostat for the period 2004 - 2006 we can state that the most of Slovak enterprises, either alone or in cooperation with the group of enterprises developed product or process innovation. The new product was developed by 733 enterprises and the new process by 580 enterprises. We can also say that in this period were dominant industrial enterprises above the enterprises from the service and construction sector (Table 2).

Table 2 - Product and process innovation according to the developing organization and the sector of its operation in Slovak Republic

\begin{tabular}{|l|c|c|c|c|c|c|}
\hline $\begin{array}{l}\text { Sector of enterprise's } \\
\text { operation / developing } \\
\text { organization of new } \\
\text { products or processes }\end{array}$ & \multicolumn{3}{|c|}{ Product developed } & \multicolumn{3}{|c|}{ Process developed } \\
\cline { 2 - 7 } & $\begin{array}{c}\text { mainly by } \\
\text { other } \\
\text { enterprises } \\
\text { or } \\
\text { institutions }\end{array}$ & $\begin{array}{c}\text { by } \\
\text { enterprise } \\
\text { or the } \\
\text { group of } \\
\text { enterprises }\end{array}$ & $\begin{array}{c}\text { in cooperation } \\
\text { with the other } \\
\text { enterprises or } \\
\text { institutions }\end{array}$ & $\begin{array}{c}\text { mainly by } \\
\text { other } \\
\text { enterprises } \\
\text { or } \\
\text { institutions }\end{array}$ & $\begin{array}{c}\text { by } \\
\text { enterprise } \\
\text { or the } \\
\text { group of } \\
\text { enterprises }\end{array}$ & $\begin{array}{c}\text { in } \\
\text { cooperation } \\
\text { with the other } \\
\text { enterprises or } \\
\text { institutions }\end{array}$ \\
\hline Number of enterprises: & 57 & 441 & 138 & 145 & 311 & 282 \\
\hline in industry & 17 & 55 & 7 & 65 & 59 & 30 \\
\hline in construction & 35 & 237 & 98 & 94 & 210 & 146 \\
\hline in services & $\mathbf{1 0 9}$ & $\mathbf{7 3 3}$ & $\mathbf{2 4 3}$ & $\mathbf{3 0 4}$ & $\mathbf{5 8 0}$ & $\mathbf{4 5 8}$ \\
\hline Total in all sectors & & & & & & \\
\hline
\end{tabular}

Source: self elaboration according to the data from Eurostat on 13.1.2010 
In the development of new product 243 enterprises cooperated with other enterprises or institutions and in the development of new process that was nearly double number of enterprises. Again, the industrial enterprises dominated in cooperating during the development of new product or process, not enterprises from the sector of services or construction.

In the analyzed period, the enterprises used at least the possibility to develop new product or process entirely by another institution or company.

During the period 2004 - 2006, 574 of Slovak enterprises had decided to cooperate in creation and implementation of innovation with some of institutions or subjects operating in the country. The most important partners were suppliers of equipment, materials, components or software, i.e. 278 of enterprises cooperated with this partner (Table 3 ). The greatest interest in cooperation had small enterprises and their share on the total small innovative enterprises was $20.48 \%$.

For the cooperation with other enterprises within the group of enterprises had decided 128 enterprises. In this case, mainly large and medium-sized enterprises cooperate. Several enterprises also had an interest to work with a very important group, with clients and customers.

The smallest interest had Slovak enterprises in cooperation with the government or public research institutions, where only one medium-sized enterprise, two large and six small enterprises preferred this type of cooperation.

Table 3 - Number of enterprises in Slovak Republic cooperating with other institutions in regard to creation and implementation of innovation

\begin{tabular}{|l|c|c|c|c|}
\hline \multirow{2}{*}{ Cooperative institution / size of enterprises } & \multicolumn{2}{|c|}{$\begin{array}{c}\text { Total } \\
\text { number of } \\
\text { cooperative } \\
\text { enterprises }\end{array}$} & $\begin{array}{c}\text { Number of cooperative } \\
\text { enterprises according to } \\
\text { their size }\end{array}$ \\
\cline { 3 - 5 } & small & medium & large \\
\hline The cooperation of enterprises with: & & & & \\
\hline consultants, commercial labs, or private R\&D institutes & 37 & 7 & 16 & 13 \\
\hline government or public research institutes & 9 & 6 & 1 & 2 \\
\hline universities or other higher education institutions & 20 & 7 & 6 & 7 \\
\hline suppliers of equipment, materials, components or software & 278 & 179 & 61 & 38 \\
\hline clients or customers & 89 & 31 & 38 & 20 \\
\hline competitors or other enterprises of the same sector & 12 & 2 & 6 & 4 \\
\hline other enterprises within your enterprise group & 128 & 26 & 49 & 53 \\
\hline
\end{tabular}

Source: self elaboration according to the data from Eurostat on 13.1.2010

If we want to evaluate the cooperation of Slovak enterprises in the period 2004 2006 with other enterprises by the country of their operation we find out that unlike the other V4 countries, Slovak enterprises preferred the cooperation with enterprises operating in various European countries. But the difference is not 
significant (Table 4). During this period the cooperation with European countries was preferred by 489 enterprises and the cooperation with enterprises operating in the Slovak Republic was preferred by 478 enterprises. These cooperations preferred about $50 \%$ of large enterprises on the total number of innovative enterprises, followed medium-sized enterprises with approximately $30.5 \%$ share and small businesses with an average $24 \%$ share.

The cooperation with the enterprises in U.S. or in other countries was preferred by 143 Slovak enterprises, whereby dominated large enterprises.

Table 4 - Number of enterprises in Slovak Republic cooperating in creation and implementation of innovation according to the country of the partner

\begin{tabular}{|c|c|c|c|c|}
\hline \multirow[t]{2}{*}{ Cooperative institution / size of enterprises } & \multirow{2}{*}{$\begin{array}{c}\text { Total } \\
\text { number of } \\
\text { cooperative } \\
\text { enterprises }\end{array}$} & \multicolumn{3}{|c|}{$\begin{array}{c}\text { Number of cooperative } \\
\text { enterprises according to } \\
\text { their size }\end{array}$} \\
\hline & & small & medium & large \\
\hline \multicolumn{5}{|c|}{ Enterprise engaged in any type of innovation cooperation: } \\
\hline within United States and other countries & 143 & 42 & 39 & 63 \\
\hline national & 478 & 205 & 152 & 121 \\
\hline within other Europe & 489 & 214 & 151 & 125 \\
\hline
\end{tabular}

Source: self elaboration according to the data from Eurostat on 13.1.2010

\subsection{The innovation activity of Czech enterprises}

According to data available from Eurostat were in 2006 in the Czech Republic 23,337 enterprises, of which 8,164 were innovation active (Table 5). In absolute number was the largest group the group of small enterprises, in which dominated the product and process innovation, but only $28.90 \%$ of all small enterprises decided to introduce some type on innovation. The biggest contribution to innovation performance in the country had large enterprises, of which $70.41 \%$ introduced product, process or both product and process innovation. In the group of medium-sized enterprises was the number of innovative and non-innovative enterprises almost the same.

The Czech enterprises, regardless of their size, preferred in the year 2006 a combination of product and process innovations, not only product or only process innovation. 
Table 5 - Enterprises with innovation activity according to their size and the type of implemented innovation in Czech Republic

\begin{tabular}{|l|c|c|c|c|c|c|c|}
\hline \multirow{2}{*}{$\begin{array}{l}\text { Size of } \\
\text { enterprise/type } \\
\text { of innovation }\end{array}$} & $\begin{array}{c}\text { Total } \\
\text { enterprises }\end{array}$ & Total & $\begin{array}{c}\text { Product } \\
\text { and } \\
\text { process } \\
\text { innovation }\end{array}$ & $\begin{array}{c}\text { Product } \\
\text { innovation }\end{array}$ & $\begin{array}{c}\text { Establish } \\
\text { Process } \\
\text { innovation }\end{array}$ & $\begin{array}{c}\text { Enterprises } \\
\text { innovators, } \\
\text { ongoing and/or } \\
\text { innovation } \\
\text { activity }\end{array}$ \\
\hline $\begin{array}{l}\text { Small } \\
\text { enterprises }\end{array}$ & 17,362 & 5,018 & 2,156 & 1,042 & 1,594 & 226 & 12,344 \\
\hline $\begin{array}{l}\text { Medium } \\
\text { enterprises }\end{array}$ & 4,853 & 2,356 & 1,405 & 391 & 514 & 45 & 2,497 \\
\hline $\begin{array}{l}\text { Large } \\
\text { enterprises }\end{array}$ & 1,122 & 790 & 556 & 93 & 131 & 11 & 332 \\
\hline
\end{tabular}

Source: self elaboration according to the data from Eurostat on 13.1.2010

Figure 4 shows the number of innovative enterprises in different sectors. According to this we can state that the highest share had in 2006 the industrial enterprises - from the total number 13,682 industrial enterprises 5,005 of them decided to innovate their production.

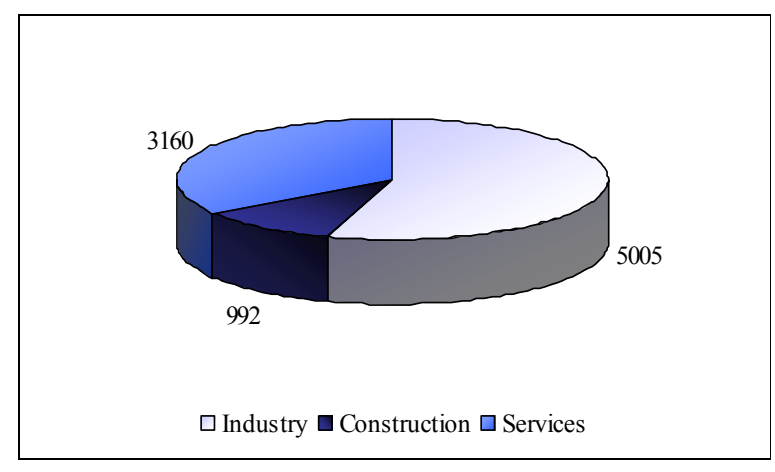

Figure 4 - The number of enterprises with innovation activity according to the sector of their operation in Czech Republic

According to the data available from Eurostat for individual sectors we can state that the largest share of industrial innovative enterprises on the total number of enterprises (75\%) was observed in Manufacture of coke, refined petroleum products and nuclear fuel. This was followed by the Production of chemicals and chemical products and Manufacture of other transport equipment, in which more than $50 \%$ of enterprises have introduced at least one of the types of innovations.

The lowest innovation activity was observed in enterprises from the sectors Mining and quarrying and Manufacture of wearing apparel; dressing; dyeing of fur. In these sectors only $20 \%$ of enterprises decided to innovate their production.

Even in the service sector dominated the enterprises without innovation activity. From the total of 9,656 enterprises in service sector were innovation active only 
3,160 enterprises. The highest activity showed the enterprises in the sector of Research and development, where even $68 \%$ of enterprises have developed and implemented some type of innovation. Then followed the enterprises dealing with Computer and related activities with $60 \%$ share on the total number of enterprises in this sector, enterprises in the Financial intermediation, except insurance and pension funds with a 55\% share, Insurance and pension funds, except compulsory social security, and also Post and telecommunications with around $53 \%$ share of innovation active enterprises on the total number of enterprises in the sector.

The lowest innovation activity was observed in the sector Real estate activities (only $16.13 \%$ of companies innovated providing services), Retail trade, except of motor vehicles, motorcycles; repair of personal and household goods. Then followed Hotels and restaurants, and the enterprises from the sector Land transport; transport via pipelines; water transport; air transport. Almost $80 \%$ of enterprises didn't introduce any type of innovation in the sector Transport, storage and communication, and in Supporting and auxiliary transport activities; activities of travel agencies.

In the year 2006 were in the construction sector 5,439 enterprises, of which only 922 have introduced either product, process or both product and process innovation. Even $81.76 \%$ of enterprises in the construction sector decided not to take the high risk associated with innovation, so they didn't implement any type of innovation. Data about enterprises according to their size and innovation, respectively non-innovation activity in construction sector are not available; therefore they will not be analyzed.

a) industry

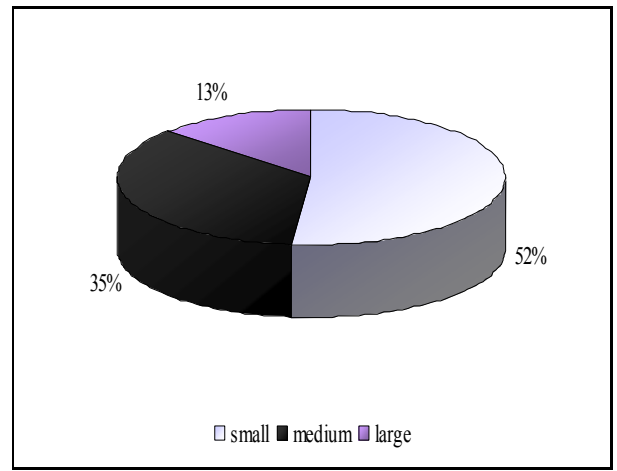

b) services

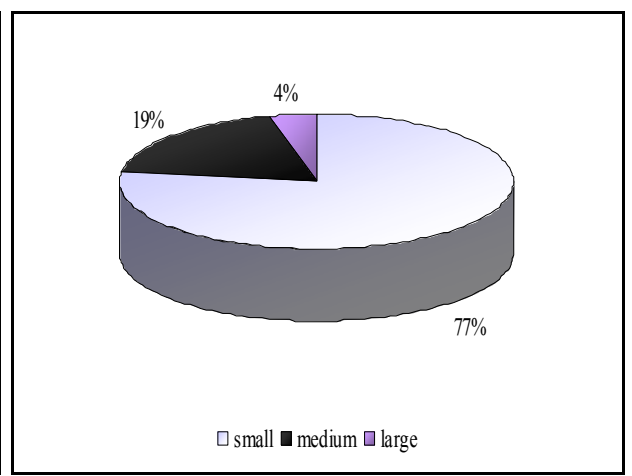

Figure 5 - Percentage share of small, medium and large innovation active enterprises in the total number of innovative enterprises in industry and services sectore in Czech Republic 
In total it can be stated that during the year 2006, the most innovation in all three sectors have introduced large enterprises, although their share on the total number of enterprises was the lowest. On the contrary, the most numerous group of enterprises (small enterprises) showed the lowest innovation activity, where from the total number of enterprises decided to take risks and spend money on product or process innovation only one third of enterprises (Figure 5).

\subsection{The cooperation in creating and implementing innovation in Czech Republic}

During the period $2004-2006$ participated on the development of new or significantly improved product and process in the Czech Republic various institutions. Enterprises preferred the use of their own in-house capacity, respectively the cooperation with a group of member companies. 4,972 enterprises developed itself product innovation and 4,400 enterprises process innovation (Table 6). It can be said, that in the development of new product dominated industries enterprises and in the development of new process were most innovation active the enterprises providing services.

Table 6 - Product and process innovation according to the developing organization and the sector of its operation in Czech Republic

\begin{tabular}{|l|c|c|c|c|c|c|}
\hline \multirow{2}{*}{$\begin{array}{l}\text { Sector of enterprise's } \\
\text { operation / developing } \\
\text { organization of new } \\
\text { products or processes }\end{array}$} & $\begin{array}{c}\text { mainly by } \\
\text { other } \\
\text { enterprises } \\
\text { or } \\
\text { institutions }\end{array}$ & $\begin{array}{c}\text { by } \\
\text { enterprise } \\
\text { or the } \\
\text { group of } \\
\text { enterprises }\end{array}$ & $\begin{array}{c}\text { in cooperation } \\
\text { with the other } \\
\text { enterprises or } \\
\text { institutions }\end{array}$ & $\begin{array}{c}\text { mainly by } \\
\text { other } \\
\text { enterprises } \\
\text { or } \\
\text { institutions }\end{array}$ & $\begin{array}{c}\text { by } \\
\text { enterprise } \\
\text { or the } \\
\text { group of } \\
\text { enterprises }\end{array}$ & $\begin{array}{c}\text { in } \\
\text { cooperation } \\
\text { with the other } \\
\text { enterprises or } \\
\text { institutions }\end{array}$ \\
\hline Number of enterprises: & & & & & & \\
\hline in industry & 323 & 2,564 & 725 & 576 & 1,971 & 1,318 \\
\hline in construction & 147 & 221 & 160 & 131 & 346 & 259 \\
\hline in services & 394 & 2187 & 720 & 579 & 2,083 & 1,553 \\
\hline Total in all sectors & $\mathbf{8 6 4}$ & $\mathbf{4 , 9 7 2}$ & $\mathbf{1 , 6 0 5}$ & $\mathbf{1 , 2 8 6}$ & $\mathbf{4 , 4 0 0}$ & $\mathbf{3 , 1 3 0}$ \\
\hline
\end{tabular}

Source: self elaboration according to the data from Eurostat on 13.1.2010

After development of new product by the enterprise itself or by other enterprises within the group, followed the cooperation with other enterprises or institutions in creation and implementation of innovative products or processes. Also in this case, the industrial enterprises most cooperate with other enterprises in the development of new product and in the development of new process dominated the enterprises from the service sector.

As the least attractive alternative for Czech enterprises was considered the alternative when the innovative product or process is developed by another 
enterprise or institution and subsequently bought by the original enterprise. The highest interest in this type on innovation had the enterprises providing services.

From the total number of innovation active enterprises operating in the Czech Republic during the years $2004-20063,122$ enterprises decided to cooperate in the process of innovation creation and implementation with various domestic institutions. The innovative enterprises preferred the cooperation with clients and customers (almost $13 \%$ of innovation active enterprises), because this group is in the process of development of new products or processes the most important (Table 7). Adapting of innovative products or processes to their requirements and ideas creates an assumption for the increased interest in these products after their introduction on the market in the future. The cooperation with suppliers of equipment, materials, components or software preferred in the development of new products or processes 976 enterprises. Then followed the cooperation with other enterprises within the group. In all three cases, the largest group of cooperating and innovative enterprises was group of small enterprises, but their share on the total number of innovative small enterprises was the lowest. The least numerous group was group of large enterprises.

The cooperation with consultants, commercial labs or private research and development institutions was preferred in the development of new products or processes during the period by 177 enterprises, including 87 medium-sized enterprises, 69 small and 21 large enterprises.

The least interest had the innovation active enterprises in cooperation with the government and public research institutions. From 61 enterprises that decided for this type of cooperation were only eight large enterprises.

Table 7 - Number of enterprises in Czech Republic cooperating with other institutions in regard to creation and implementation of innovation

\begin{tabular}{|l|c|c|c|c|}
\hline & \multicolumn{2}{|c|}{$\begin{array}{c}\text { Total } \\
\text { number of } \\
\text { cooperative } \\
\text { enterprises }\end{array}$} & \multicolumn{2}{|c|}{$\begin{array}{c}\text { Number of cooperative } \\
\text { enterprises according to } \\
\text { their size }\end{array}$} \\
\cline { 3 - 5 } & small & medium & large \\
\hline The cooperation of enterprises with: & & & & \\
\hline consultants, commercial labs, or private R\&D institutes & 177 & 69 & 87 & 21 \\
\hline government or public research institutes & 61 & 31 & 22 & 8 \\
\hline universities or other higher education institutions & 122 & 31 & 49 & 43 \\
\hline suppliers of equipment, materials, components or software & 976 & 538 & 318 & 120 \\
\hline clients or customers & 1,060 & 552 & 361 & 147 \\
\hline competitors or other enterprises of the same sector & 133 & 72 & 40 & 21 \\
\hline other enterprises within your enterprise group & 593 & 250 & 181 & 161 \\
\hline
\end{tabular}

Source: self elaboration according to the data from Eurostat on 13.1.2010

The cooperation of enterprises and institutions in developing and introducing innovation can be observed also in geographical terms. During the period $2004-$ 
2006 most Czech enterprises cooperated mainly at the national level (Table 8). In developing and introducing innovative products or processes, 2,719 enterprises decided to cooperate with domestic enterprises operating in the Czech Republic. From the total number of innovation active large enterprises cooperated at national level 459 enterprises, i.e. $58.10 \%$. Small cooperating enterprises were three times more than large enterprises, but their share on the total number of small innovating enterprises was only $28.06 \%$.

Some enterprises during the period decided to use the cooperation with other enterprises and institutions operating outside the Czech Republic. From the total number of innovative enterprises cooperated with the enterprises in other European countries 1,934 enterprises, i.e. $23.7 \%$, and 604 enterprises decided to cooperate with enterprises operating in the U.S. and other countries of the World.

Table 8 - Number of enterprises in Czech Republic cooperating in creation and implementation of innovation according to the country of the partner

\begin{tabular}{|l|c|c|c|c|}
\hline \multirow{2}{*}{ Cooperative institution / size of enterprises } & \multicolumn{3}{|c|}{$\begin{array}{c}\text { Total } \\
\text { number of } \\
\text { cooperative } \\
\text { enterprises }\end{array}$} & \multicolumn{2}{|c|}{$\begin{array}{c}\text { Number of cooperative } \\
\text { enterprises according to } \\
\text { their size }\end{array}$} \\
\cline { 3 - 5 } & & & & \\
\hline Enterprise engaged in any type of innovation cooperation: & & & & \\
\hline within United States and other countries & 604 & 286 & 190 & 128 \\
\hline national & 2,719 & 1,408 & 852 & 459 \\
\hline within other Europe & 1,934 & 859 & 674 & 401 \\
\hline
\end{tabular}

Source: self elaboration according to the data from Eurostat on 13.1.2010

In terms of size of enterprises was the most numerous group of cooperating enterprises group of small enterprises, but their share on the total number of innovation active enterprises was the lowest. $28.06 \%$ of small enterprises cooperated with other enterprises in the area of innovation at national level, $17.12 \%$ of enterprises cooperated with enterprises in other European countries and only $5.70 \%$ of small enterprises decided for cooperation with the enterprises in the U.S. or in other countries of the World. On the contrary, the least numerous group of enterprises was group of large enterprises, of which only $58.10 \%$ cooperated with other enterprises at the national level, $50.76 \%$ cooperated with other European enterprises and $16.20 \%$ of enterprises preferred cooperation in developing and implementing innovation with enterprises that operate in other countries of the World.

\section{CONCLUSION}

The article deals with the theoretical definition of innovation by different authors and with the short defining different types of innovation. The analytical part of this paper describes the innovation activities of Slovak and Czech enterprises, in 
which in 2006 was dominated an interest in introducing both product and process innovation, not only product or only process innovation. In absolute values was the largest group of enterprises introducing some type of innovation in both countries the group of small enterprises. From the perspective of the sector of operation of these enterprises in 2006 were the most innovation active industrial enterprises. The least innovation introduced enterprises from the construction sector.

On the development of new or significantly improved product or process in the period $2004-2006$ have participated various institutions. The enterprises in all three sectors preferred development of product or process by their own enterprise or within the enterprise group before the cooperation with other enterprises or institutions.

From the perspective of the cooperating enterprises or institutions, Slovak enterprises cooperated in creation and implementation of innovation mainly with the suppliers of equipment, materials, components or software. Czech enterprises preferred cooperation with clients and customers. The least interest had innovative enterprises in both analyzed countries in cooperation with the government or public research institutions.

The last part of the analysis is focused on the cooperation of enterprises from the national point of view. During the period 2004 - 2006 Slovak enterprises preferred cooperation with enterprises in other European countries and Czech enterprises preferred cooperation with enterprises at national level. The lowest interest of innovation active enterprises was observed in cooperation with enterprises operating in the U.S. or in other countries of the World.

\section{REFERENCES}

AMABILE, T. M. (1996), Creativity in Context: Update to The Social Psychology of Creativity, 1. edition, Westview Press, 336 p., ISBN-10: 0813330343.

DAVILA, T. - EPSTEIN, M. J. - SHELTON, R. (2006), Making Innovation Work: How to Manage It, Measure It, and Profit from It. United Kingdom: Wharton School Publishing, 368 p., ISBN 0-13-149786-3.

KLAS, A. et all. (2005), Technologický a inovačný rozvoj v Slovenskej republike, Bratislava: SAV, 390 p., ISBN 80-7144-147-3.

LUECKE, R. - KATZ, R. (2003), Managing Creativity and Innovation, Boston: Harvard Business School Press, 174 p., ISBN 1-59139-112-1.

Návrh zákona o inováciách, Retireved from http://www.economy.gov.sk/pk/882007-1000/ma.htm.

Český Statistický úřad: Retrieved 2010-09-10, from: www.czso.cz. 
OECD: Oslo manual - Guidelines for Collecting and Interpreting Innovation Data, 3rd Edition, DSTI, OECD, Paris, 2005. Retrieved 12.01.2009, from http://www.ttgv.org.tr/UserFiles/File/OSLO-EN.pdf.

PÜRSTINGER, G. (2005), “The European Innovation - Challenge”, In Kvalita Inovácia Prosperita - Quality Innovation Prosperity, Vol. IX, No. 1, 2005, p. 71 - 87, ISSN: 1335-1745.

Rada pro výzkum, vývoj a inovace: Retrieved 2010-09-10, from www.vyzkum.cz.

Štatistický úrad Európskeho Spoločenstva: Retrieved 2010-09-10, from http://epp.eurostat.ec.europa.eu/ portal/page/portal/science_technology_innovation/data/database.

Štatistický úrad SR: Inovačná aktivita podnikov v SR v rokoch 2004 - 2006, Retrieved 2010-09-10, from: www.statistics.sk.

\section{ABOUT THE AUTHOR}

Ing. Emília Spišáková - Technical University of Košice, Faculty of Economy, Department of Economics Theories, Němcovej 32, 04001 Košice, Slovak Republic, e-mail: emilia.spisakova@tuke.sk 